\title{
Endoscopic Cauterization Versus Clipping of Sphenopalatine Artery in the Management of Intractable Posterior Epistaxis
}

\author{
IBRAHIM T. EL-SHAMY, M.Sc.*; EMAD M. SHEHATA, M.D.**; MAGDY E. SAFAN, M.D.*** and \\ AHMED M. GAMEA, M.D.*** \\ The Departments of Otorhinolaryngology*, Audiology** and Otolaryngology***, Faculty of Medicine, Tanta University
}

\begin{abstract}
Background: Endoscopic ligation of the sphenopalatine artery is a safe, simple and effective procedure in the management of refractory posterior epistaxis. Both modalities (cauterization, clipping) show good efficacy in controlling posterior epistaxis with slight advantage of clipping that it showed less post-operative complications.
\end{abstract}

The Aim of study: This work was to compare the efficacy of endoscopic sphenopalatine artery cauterization versus clipping in the management of intractable posterior epistaxis.

Patients and Methods: Forty patients were selected for this prospective study in the period between October 2016 to April 2017 at Otolaryngology Department, Tanta University Hospital complaining of recurrent epistaxis (26 males and 14 females). The patient ages ranges between 18-60 years. We selected patients who didn't have history of sinonasal trauma, tumours or bleeding disorders. Twenty patients of the study had an endoscopic sphenopalatine artery clipping, the other twenty had sphenopalatine artery cauterization. The choice between the two surgical techniques has been randomized and all patients have been operated by the same doctor.

Results: Among the first group who had SPA cauterization 5 patients had recurrent epistaxis in the $4^{\text {th }}, 5$ th, 6 th 8 th day and after 1 month respectively thus success rate among this group is $75 \%$. Two patients in the group who had sphenopalatine artery clipping had recurrent epistaxis in the $6^{\text {th }}$ and $7 \mathrm{t}^{\mathrm{h}}$ day with success rate $90 \%$.

Conclusions: Both modalities (cauterization, clipping) show good efficacy in controlling posterior epistaxis with slight advantage of clipping that it showed less post-operative complications.

Key Words: Sever epistaxis - Sphenopalatine artery - Endoscpic clipping - Cauterization of sphenopalatine artery.

Correspondence to: Dr. Ibrahim T. El-Shamy,

The Department of Otorhinolaryngology, Faculty of Medicine, Tanta University

\section{Introduction}

EPISTAXIS is defined as acute hemorrhage from the nostril, nasal cavity or nasopharynx [1] . It is the most common nasal emergency requiring hospital admission [2].

The main source of blood in the nasal cavity is the Sphenopalatine Artery (SPA), which is involved in most severe epistaxis episodes $[3,4]$. The sphenopalatine artery is the main blood supply to the posterior area of the nasal fossa. It is a terminal branch of the internal maxillary artery, which in turn is a branch of the external carotid artery. It leaves the pterygopalatine fossa through the sphenopalatine foramen to enter the nasal fossa.

Intractable epistaxis is defined as recurrent bleeding of unidentified origin and bleeding not controlled by at least one trial of standard nasal packing [5].

Sphenopalatine artery ligation is performed in cases of ongoing hemorrhage despite the above methods. The procedure is performed under direct rigid endoscopy and the vessel is either clipped or coagulated using bipolar diathermy. Success rates are reported to be better than other forms of arterial ligation, probably because it is an end artery with little collateral flow [6].

One anatomical landmark to find the sphenopalatine artery is the lateral insertion of the middle turbinate in to the palatine known as the ethmoidal crest appearing in the lateral nasal wall, marking the anterior margin of the foramen [7].

\section{Patients and Methods}

This prospective study was carried out in ORL Department Tanta University Hospital. Forty pa- 
tients with intractable posterior epistaxis were enrolled in this study. Case enrollment has started from October 2016 and the duration of the study was 6 months. The patients were divided into 2 groups:

Group 1: 20 patients in whom SPA cauterization was done.

Group 2: 20 patients in whom SPA clipping was done.

The choice between the two surgical techniques has been blindly randomized and all patients were operated by the same doctor. All patients provided written informed consent according to a protocol approved by Ethical Committee of Tanta Faculty of Medicine.

Adequate provision to maintain privacy of participants and confidentiality of data were taken, every patient signed a written consent to participate in the study and was given a secret code number. All data of the patients was secret and not published by any means.

After surgery routine follow-up consisted of anterior rhinoscopy and endoscopic nasal examination weekly up to 2 months.

A vertical incision was made through the mucosa and periosteum $1 \mathrm{~cm}$ anterior to the posterior tip of the middle turbinate. A free elevator was used to raise a mucoperiosteal flap posteriorly and superiorly.

The neurovascular bundle exiting the foramen emerges in a horizontal plane. After identifying the artery, either diathermy using a bipolar grasping forceps could be done or using Liga clips over the artery as it exits the foramen or its branches if it branches inside the foramen.

After surgery the patient had to take systemic antibiotic to prevent rhino sinusitis and possibly toxic shock syndrome. Topical vasoconstriction nasal drops and antifibrinolytic agents (tranexamic acid) were used. Avoidance of aspirin and other non-steroidal anti-inflammatory drugs was advised.

\section{Results}

This study was conducted on 40 patients, 26 male and 14 females ranging in age from 18 to 60 with recurrent epistaxis. Endoscopic spa artery ligation either through cauterization or clipping had been done for all patients (Table 1).
Table (1): Sex distribution

\begin{tabular}{lllllll}
\hline \multirow{2}{*}{ Sex } & \multicolumn{2}{c}{$\begin{array}{c}\text { Cauterization } \\
(\mathrm{N}=20)\end{array}$} & \multicolumn{2}{c}{$\begin{array}{c}\text { Clipping } \\
(\mathrm{N}=20)\end{array}$} & \multirow{2}{*}{$\mathrm{x}^{2}$} & $\begin{array}{c}p \text { - } \\
\text { value }\end{array}$ \\
\cline { 2 - 5 } & $\mathrm{N}$ & $\%$ & $\mathrm{~N}$ & $\%$ & & \\
\hline Male & 12 & 60 & 14 & 70 & 0.443 & 0.507 \\
Female & 8 & 40 & 6 & 30 & & \\
\hline
\end{tabular}

There was no correlation between sex and age with results of our study.

The average time of SPA ligation in our study is about 45 minute.in our study patients who required longer operation time more than 1 hour was as follows; two patients among cauterization group required more than hour to cauterize the SPA artery while four patients among clipping group had operation time more than 1 hour (Table 2).

Table (2): Cases with operation time more than 1 hour.

\begin{tabular}{lllllll}
\hline & \multicolumn{2}{c}{$\begin{array}{c}\text { Cauterization } \\
(\mathrm{N}=20)\end{array}$} & \multicolumn{2}{c}{$\begin{array}{c}\text { Clipping } \\
(\mathrm{N}=20)\end{array}$} & $\mathrm{x}^{2}$ & $\begin{array}{c}p- \\
\text { value }\end{array}$ \\
\cline { 2 - 8 } & $\mathrm{N}$ & $\mathbf{\%}$ & $\mathbf{N}$ & $\%$ & & \\
\hline Operation time $^{<1}$ hour & 2 & 10 & $\mathbf{4}$ & 20 & 0.783 & 0.376 \\
\hline
\end{tabular}

Post-operative complication in both groups of patients was observed. In the group who had SPA cauterization 5 patients $(25 \%)$ had recurrent epistaxis, 1 patient ( $5 \%$ ) had paresthesia in soft palate, 3 patients $(15 \%)$ had nasal crustation, 3 patients $(15 \%)$ had synechia and 2 patients $(10 \%)$ had sinusitis while the other 16 patients $(80 \%)$ of this group showed no post-operative complication.

Regarding the other group of patients who had SPA clipping 2 patients $(10 \%)$ had recurrent postoperative epistaxis while the other 18 patients $(90 \%)$ showed no postoperative complication (Table 3) Fig. (1).

Table (3): Post-operative complication in both groups of patients.

\begin{tabular}{|c|c|c|c|c|c|c|}
\hline & \multicolumn{2}{|c|}{$\begin{array}{c}\text { Cauterization } \\
(\mathrm{N}=20)\end{array}$} & \multicolumn{2}{|c|}{$\begin{array}{l}\text { Clipping } \\
(\mathrm{N}=20)\end{array}$} & \multirow{2}{*}{$x^{2}$} & \multirow{2}{*}{$\begin{array}{c}p- \\
\text { value }\end{array}$} \\
\hline & $\mathrm{N}$ & $\%$ & $\mathrm{~N}$ & $\%$ & & \\
\hline - Recurrent epistaxis & 5 & 25 & 2 & 10 & 1.562 & 0.212 \\
\hline $\begin{array}{l}\text { - Paresthesia in soft palate } \\
\text { or nose }\end{array}$ & 1 & 5 & 0 & 0 & 1.032 & 0.311 \\
\hline - Nasal crusting & 3 & 15 & 0 & 0 & 3.241 & 0.072 \\
\hline - Facial swelling & 0 & 0 & 0 & 0 & - & - \\
\hline - Septal perforation & 0 & 0 & 0 & 0 & - & - \\
\hline $\begin{array}{l}\text { - Necrosis of inferior } \\
\text { turbinate }\end{array}$ & 0 & 0 & 0 & 0 & - & - \\
\hline - Synechia & 3 & 15 & 0 & 0 & 3.241 & 0.072 \\
\hline - Sinusitis & 2 & 10 & 0 & 0 & 2.113 & 0.147 \\
\hline • None & 16 & 80 & 18 & 90 & 2.063 & 0.151 \\
\hline
\end{tabular}




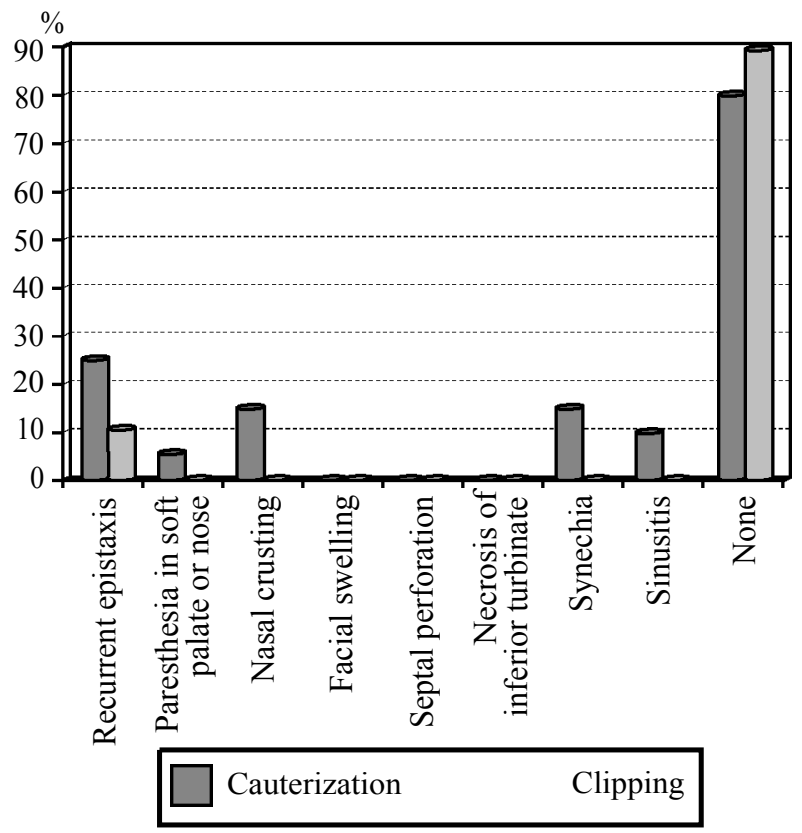

Fig. (1): Showing post-operative complications in both groups of patients.

Our study showed that patients who sphenopalatine artery clipping had less post-operative complications than clipping group.

As regard as type of post-operative recurrent epistaxis in both groups of patients; in the group who had SPA cauterization 4 patients $(20 \%)$ had early recurrent post-operative bleeding (at the 4 th, 5 th, 6 th and 8 th day after operation) and 1 patient (5\%) had bleeding 1 month after operation while in the other group of patients who had SPA clipping 2 patients had early recurrent bleeding in 6 th day and 1 week after operation (Table 4) Fig. (2).

Majority of cases of the study were hospitalized 24 hours after operation for follow-up, five patients required more hospitalization time. 3 patients among cauterization group were hospitalized for more than 2 days till stabilization of general condition while 2 patients among clipping group were hospitalized for more than 2 days.

Three of the cases that had recurrent epistaxis required further surgical intervention to control epistaxis, two cases in which epistaxis relapsed after sphenopalatine artery cauterization were ultimately resolved after a review procedure was performed and the remaining terminal branches of the artery and the anterior ethmoidal artery were ligated. The third case in which epistaxis relapsed after sphenopalatine artery clipping. The patient was examined under general anesthesia and slippage of the clip was found to be the cause of recurrence of epistaxis; reclipping was done and the epistaxis was controlled.
Table (4): Type of post-operative recurrent epistaxis in both groups of patients.

\begin{tabular}{|c|c|c|c|c|c|c|}
\hline & \multicolumn{2}{|c|}{$\begin{array}{l}\text { Cauterization } \\
\qquad(\mathrm{N}=20)\end{array}$} & \multicolumn{2}{|c|}{$\begin{array}{l}\text { Clipping } \\
(\mathrm{N}=20)\end{array}$} & \multirow{2}{*}{$x^{2}$} & \multirow{2}{*}{$\begin{array}{c}p- \\
\text { value }\end{array}$} \\
\hline & $\mathrm{N}$ & $\%$ & $\mathrm{~N}$ & $\%$ & & \\
\hline $\begin{array}{l}\text { - Immediate: Post- } \\
\text { operative period (24h.) }\end{array}$ & 0 & 0 & 0 & 0 & - & - \\
\hline $\begin{array}{l}\text { Early: Post-operative } \\
\text { period }(24 \mathrm{~h}-2 \mathrm{w})\end{array}$ & 4 & 20 & 2 & 10 & 0.783 & 0.376 \\
\hline - Bleeding after 2 weeks. & 1 & 5 & 0 & 0 & 1.032 & 0.311 \\
\hline
\end{tabular}

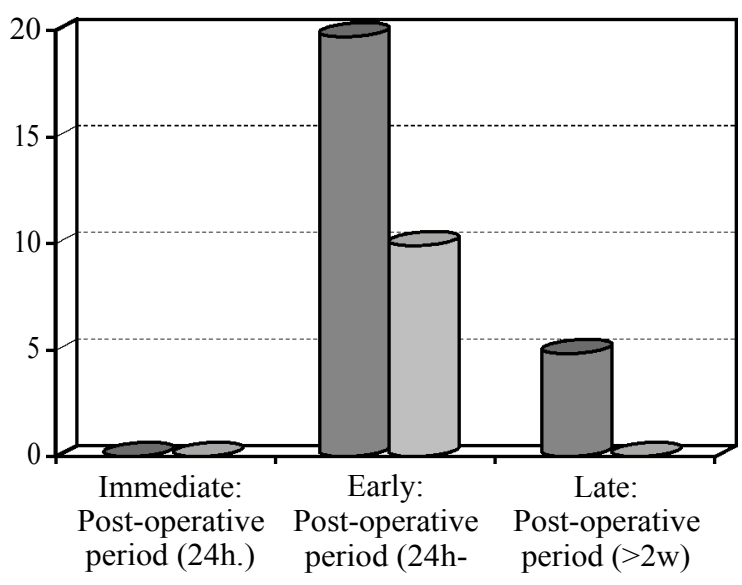

Cauterization

Clipping

Fig. (2): Showing type of post-operative recurrent epistaxis in both patient groups.

\section{Discussion}

The aim of this study was to compare the efficacy of cauterization versus clipping of sphenopalatine artery in management of sever recurrent epistaxis.

Twenty patients of the study had an endoscopic sphenopalatine artery clipping, the other 20 had sphenopalatine artery cauterization. The study shows that among the 20 patients who had SPA clipping 2 patients had early post-operative bleeding in the 6 th day and one week after operation, among the other group who had sphenopalatine cauterization 4 patients had early post-operative bleeding at $4^{\text {th }, ~} 5$ th, 6 th and 8 th days and one had late postoperative bleeding one month after operation and $82.5 \%$ of patients $(n=33)$ showed no post-operative recurrent epistaxis.

Besides recurrent bleeding; some patients of the study showed other complications as follows; $(7.5 \%)$ of them $(n=3)$ showed nasal crusting all of them were among the group that had SPA cauterization, $(3.5 \%)$ of them $(n=3)$ showed synechia also were among the group that had SPA cauterization, 
$5 \%$ of them $(n=2)$ showed signs of sinusitis also among the group that had spa cauterization. One patient of those who had SPA cauterization complained of paresthesia in soft palate.

The study showed the efficacy of sphenopalatine artery ligation in the management of refractory posterior epistaxis with overall success rate $82.5 \%$ with less complication compared to other measures.

The two modalities (SPA cauterization and clipping) have showed good efficacy in the control of epistaxis with advantage of SPA clipping over cauterization that it shows less post-operative complication as adhesion and synechia which makes it difficult to assess the exact location of the artery in the postoperative period because of discoloration of the mucosa. In the presence of hemoclips, observation of the clip may be used for determining the location of the artery.

Barlow et al., [8] have shown a strong association between surgery for epistaxis and need for blood transfusion. Likewise, Voegels et al., [9] reported similar rates of blood transfusion (45.5\%) in patients submitted to sphenopalatine artery ligation. These findings support the idea that, in severe cases and patients at risk for hemodynamic instability, earlier surgery could reduce the need for blood transfusion. None of the patients had complaints or complications connected to the surgical procedure done to manage their epistaxis, proving the safety of the method [9]

In our study there were some complications related to use of diathermy like synechiae and crustation. Our study agrees with the role of early surgical intervention in reducing the need for blood transfusion.

Rockey J.G. and Anand R. aimed to study the efficacy of sphenopalatine artery ligation/diathermy. The study was made on 10 patients required sphenopalatine artery ligation/diathermy. The age of these patients ranged between 53 and 79 years. They found a failure rate of $33 \%$ for sphenopalatine artery ligation/diathermy. It may be that it was a part of a learning curve, as surgeons ( 2 consultants and a register) got to grips with the relatively new procedure. The surgical treatment failed in three patients, one patient had had sphenopalatine artery diathermy and the other two had had sphenopalatine artery clipping. The failures were all noted to have ongoing epistaxis within the first twenty-four hours post-operatively [10].

In our study all cases were operated by the same surgeon. Our study included larger number of cases, besides recurrent epistaxis was not limited to the first 24 hours.

S.A. Reza et al., made a retrospective chart review of patients undergoing Sphenopalatine artery ligation between January 1995 and 2005. Sixty-seven patients underwent 71 operations to occlude the sphenopalatine artery to treat epistaxis refractory to conservative therapy [11]. In $45 \%$ of cases, an intranasal clip was the only method of ligating the SPA, and $14 \%$ of patients received SPA diathermy only. In $41 \%$ of patients, both clip ligation and diathermy were used. Early operative failure, defined as the need to control recurrent epistaxis within 2 weeks of the procedure occurred in eight patients although none required operative re-intervention. Factors independently associated with early re-bleeding were the patient's platelet count on admission, and whether intranasal diathermy was used to coagulate the sphenopalatine artery. Not using diathermy was also a significant and strong predictor of the likelihood of long-term success of the procedure [11].

In our study; patients with coagulation problems like low platelet count were excluded. The use of intranasal diathermy was associated with higher incidence of certain post-operative complication like crustations and synechia which besides mucosal changes makes it more difficult to identify the bleeding point in a review surgery.

\section{Conclusion:}

The procedure appears to be safe, simple, fast and effective for the management of intractable posterior epistaxis with low rates of morbidity and complications.

It should be considered as an immediate secondline management when conservative treatment fails. Some experts even recommend its use as a first option, without waiting for failure of posterior packing.

Both modalities (cauterization, clipping) show good efficacy in controlling posterior epistaxis with slight advantage of clipping that it showed less post-operative complications.

\section{Limitation:}

Further clinical trials with a larger number of participants to assess the efficacy of endoscopic sphenopalatine artery cauterization versus clipping.

Another clinical trial to assess the efficacy of combination of both techniques for management of sever posterior epistaxis. 


\section{Acknowledgments:}

NAD.

Funding:

The research was done in Tanta University Hospital with no other funding resources.

\section{Conflicts of interest:}

No conflicts of interest declared.

\section{Authors' contributions:}

All authors had equal role in design, work, statistical analysis and manuscript writing.

\section{References}

1- BERTRAND B., ELOY P., ROMBAUX P., et al.: Guidelines to the managment of epistaxis. B. ENT, 27, 2005.

2- PALLIN D.J., CHNG Y.M., McKAY M.P., et al.: Epidemiology of epistaxis in US Emergency Departments, 1992 to 2001. Annals of emergency medicine.

3- REZENDE G.L., SOARES V.Y.R., MORAES W.C., et al.: Artéria esfenopalatina: Desafio cirúrgico na epistaxe. Brazilian Journal of Otorhinolaryngology, 78: 42-7, 2012.

4- WALKER T., MACFARLANE T. and McGARRY G. The epidemiology and chronobiology of epistaxis: An investigation of Scottish hospital admissions 1995-2004. Clinical Otolaryngology, 32 (5): 361-5, 2007.
5- LIU Y., ZHENG C., WEI W., et al.: Management of intractable epistaxis: Endoscopy or nasal packing? The Journal of Laryngology \& Otology, 126 (5): 482-6, 2012.

6- PLETCHER S.D. and METSON R.: Endoscopic ligation of the anterior ethmoid artery. The Laryngoscope, 117 (2): 378-81, 2007.

7- LEE H.Y., KIM H.U., KIM S.S., et al.: Surgical anatomy of the sphenopalatine artery in lateral nasal wall. The Laryngoscope, 112 (10): 1813-8, 2002.

8- BARLOW D.W., DELEYIANNIS F.W.B. and PINCZOWER E.F.: Effectiveness of surgical management of epistaxis at a tertiary care center. The Laryngoscope, 107 (1): 214, 1997.

9- VOEGELS R.L., THOMÉ D.C., ITURRALDE P.P.V., et al.: Endoscopic ligature of the sphenopalatine artery for severe posterior epistaxis. Otolaryngology-Head and Neck Surgery, 124 (4): 464-7, 2001.

10- SHRESTHA B.: Endoscopic Sphenopalatine Artery Cauterization in Recurrent Posterior Epistaxis: An Experience at Dhulikhel Hospital, Kathmandu University Hospital. Kathmandu University Medical Journal, 12 (1): 85-6, 2015.

11- KAMANI T., SHAW S., ALI A., et al.: Sphenopalatinesphenopalatine anastomosis: A unique cause of intractable epistaxis, safely treated with microcatheter embolization: A case report. Journal of medical case reports, 1 (1): 125, 2007. 


\section{مقارنة بين كى الشريان الوتلى الحلقى وتلبيسه للتحكيم

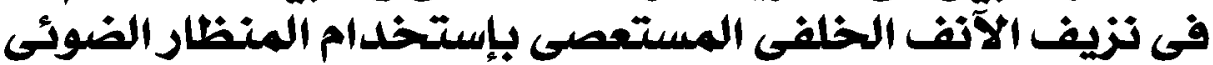

مقدمة: يعتبر ريط الشريان الوتدى الحلقى طريقة فعالة للتحكم فى نزيف الآنفى الخلفى المستعصى. كلتا طريقتى الربط آما كى الشريان

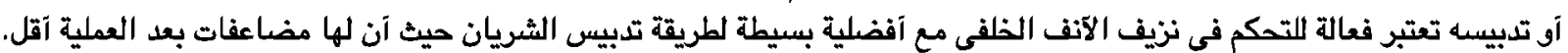
الهدف من الدراسة: تهدف هذه الدراسة إلى المقارنة بين مدى كى فعالية كى الشريان الوتدى الحلقى وتدبيسه بإستخدام المنظار الضوئى المباشر في علاج نزيف الآنف الخلفى المتكرد.

المرضى وطرق البحث: هذه الدراسة تمت بقسم الآنف والآنن والحنجرة بمستشفى جامعة طنمطا على آربعين حالة متتابعة من حالات نزيف الآتف المستعصية بداية من شهر آكتوبر 17 . ب ولمدة 7 شهود.

تم تقسيم المرضى عشوائيا إلى مجموعتين المجموعة الآولى خضعت لعملية كى الشريان الوتدى الحلقى فى حين خضعت المجموعة الآخرى لريط الشريان الوتدى الحلقى بإستخدام دبابيس الربط.

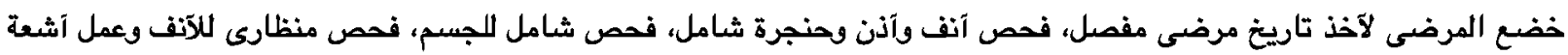

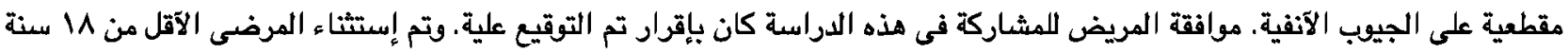

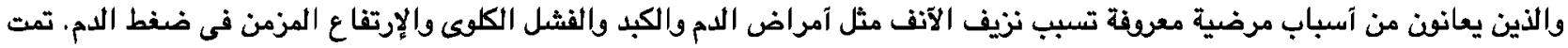
متابعة المرضى عن طريق الفحص الآمامى للآنف ويواسطة المنظار الضونئى المباشر آسبوعيا ولمدة شهرين بعد إجراء الماءئ العلملية.

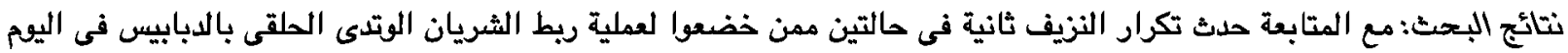

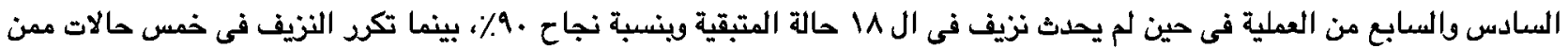

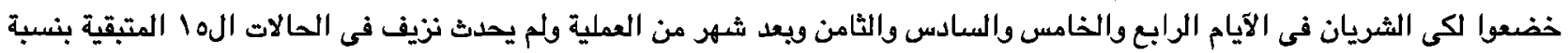

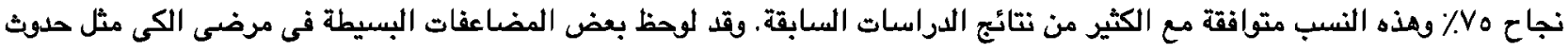
بضض الإلتصاق بالآنف آو إلتهابات الجيوب الآنفية. الإستتتاج: كلتا طريقتى الريط إما كى الشريان آو تدبيسه تعتبر فعالة للتحكم فى نزيف الآنف الخلفى مع آفضلية بسيطة لطريقة تدبيس 